\title{
Karakteristik Pendidikan Agama Kristen dalam Keluarga bagi Pembentukan Karakter Anak di Era Disrupsi 4.0
}

\author{
Debora Nugrahenny Christimoty ${ }^{1}$, Dixon Nixon Siathen ${ }^{2}$ \\ 1,2Sekolah Tinggi Teologi Baptis Indonesia, Semarang \\ 1ㄹebora@stbi.ac.id, 2nixon@stbi.ac.id
}

\begin{abstract}
In the era of disruption, there have been many changes in various fields. The negative impact that occurs on children is the occurrence of a character crisis. The family as the smallest social system has a great influence on the formation of children's character. That is why PAK in the family is very necessary for character building so as to produce children with Christ's character. The purpose of this research is to describe the characteristics of PAK in the family for the formation of children's character in the era of disruption. This research uses a qualitative descriptive method and is a literature research. The result of this research is a description of the four characteristics of PAK in the family for the formation of children's character in the era of disruption, namely: Education that helps children to believe and accept the Lord Jesus as personal Lord and Savior, Education that instills in children's hearts to have a heart that fears God, Education that adheres to a holy standard of living and divine life values, and Education that helps children have a life perspective based on the Bible.
\end{abstract}

Keywords: character; characteristics; Christian education; Christian family

\begin{abstract}
Abstrak: Di era disrupsi terjadi banyak perubahan daIam berbagai bidang. Dampak negatif yang terjadi pada anak adalah terjadinya krisiskarakter. Keluarga sebagai sistem sosialterkecilmemiliki pengaruh yang besar dalam pembentukan karakter anak.Itulah sebabnya PAK daIam keluarga sangat diperIukan bagi pembentukan karakter sehingga menghasilkan anak-anak yang berkarakter Kristus. Tujuan dari penelitian ini adaIah untuk mendeskripsikan karakterik PAK dalam keluarga bagi pembentukan karakter anak di era disrupsi. Penelitian ini menggunakan metode deskriptif kualitatif dan merupakan peneIitian kepustakaan. Hasil peneIitian ini adalah deskripsi tentang empat karakteristik PAK daIam keIuarga bagi pembentukan karakter anak di era disrupsi, yaitu: Pendidikan yang menolong anak untuk percaya dan menerima Tuhan Yesus sebagai Tuhan dan Juruselamat pribadi, Pendidikan yang menanamkan dalam hati anak untuk memiliki hati yang takut akan TUHAN, Pendidikan yang berpegang pada standar hidup kudus dan nilai hidup IIahi, dan Pendidikan yang menolong anak memiliki perspektif hidup berdasarkan AIkitab.
\end{abstract}

Kata kunci: karakter; karakteristik; keIuarga Kristen; pendidikan agama Kristen

\section{PENDAHULUAN}

Perkembangan teknologi membuat dunia menjadi terbuka seolah tanpa batas. Dijaman yang semakin modern, perkembangan teknologi di Indonesia kian hari kian bertambah, terbukti dengan banyaknya pengguna gadget dari usia dewasa sampai dengan anak usia dini. Semua orang dapat mengakses berbagai informasi 
yang diperlukan melalui ponselnya. ${ }^{1}$ Perkembangan teknologi memberi pengaruh yang besar di era disrupsi. Banyak perubahan yang terjadi di Era disrupsi sekarang ini, baik perubahan yang berdampak positif dalam kehidupan maupun dampak negatif bagi kehidupan sehari-hari, khususnya dalam hal karakter. ${ }^{2}$ Perubahan tersebut juga dialami oleh anak yang merupakan generasi penerus gereja dan bangsa ini. Saat ini sebagian besar anak mengalami masalah krisis karakter, di mana mereka tidak terkontrol oleh pengaruh negatif dari perkembangan IImu Pengetahuan dan Teknologi. ${ }^{3}$ Pada masa ini Gereja-gereja membutuhkan seorang pemimpin yang berkarakter Kristus. Namun, apa yang akan terjadi di masa kini dan masa depan jika anak sebagai generasi penerus kepemimpinan gereja tidak memiliki karakter Kristus? Itulah sebabnya diperlukan Pendidikan Agama Kristen (PAK) dalam keluarga sebagai pendidikan pertama bagi anak/generasi penerus Gereja dan bangsa ini.

Sebagai sistem sosial terkecil, keIuarga memiliki pengaruh Iuar biasa dalam haI pembentukan karakter anak. ${ }^{4}$ Alkitab menjelaskan, "DemikianIah setiap pohon yang baik menghasilkan buah yang baik, sedang pohon yang tidak baik menghasilkan buah yang tidak baik. Tidak mungkin pohon yang baik itu menghasilkan buah yang tidak baik, ataupun pohon yang tidak baik itu menghasilkan buah yang baik" (Mat. 7:17-18). Keputusan, didikan, dan nilai-nilai dari generasi terdahulu sangat mempengaruhi kehidupan generasi berikutnya. Hal ini sesuai dengan pendapatpara ahIi psikologi dan pendidikan yang menyatakan bahwa Iingkungan dan agen yang banyak mempengaruhi pembentukan karakter, iman, dan tatanilai seseorang adaIah keIuarga asaI. Keluarga asaI dianggap memiliki peran yang paling besar dan berharga dengan berbagai dinamika dan kondisi apapun dalam membentuk karakter dan kebiasaan seseorang. ${ }^{5}$ Perkembangan karakter seorang anak generasi muda dipengaruhi oleh perIakuan keIuarga dan Iingkungan terhadapnya. ${ }^{6}$

Karakter anak terbentuk sejak dini, dalam haI ini peran keIuarga memiliki pengaruh yang besar. ${ }^{7}$ Wofford menjelaskan, "DaIam pengajaranNya, Yesus sangat menekankan karakter kepada para murid-Nya. Karakter itu meliputi: integritas, kemurnian moraI, hubungan yang erat dengan Kristus, sukacita, kekudusan, keIe-

1Yusmi Warisyah, "Prosiding Seminar Nasional Pendidikan Pentingnya 'Pendampingan Dialogis' Orang Tua Dalam Penggunaan Gadget Pada Anak Usia Dini,” Proseding Seminar Nasional Pendidikan (2015).

${ }^{2}$ Rahmi Diana et al., "Pendidikan Karakter Berbasis Multiple Intelligence Sebagai Desain Pembelajaran Di Era Disrupsi," Konaspi (2012).

${ }^{3}$ Arozatulo Telaumbanua, "Peranan Guru Pendidikan Agama Kristen Dalam Membentuk Karakter Siswa,” FIDEl: Jurnal Teologi Sistematika dan Praktika (2018).

${ }^{4} Y o n a t a n$ Alex Arifianto, "Pentingnya Pendidikan Kristen Dalam Membangun Kerohanian Keluarga Di Masa Pandemi Covid-19," Regula Fidei Jurnal Pendidikan Agama Kristen (2020).

${ }^{5}$ Sijabat, B.S. Membesarkan Anak dengan Kreatif (Yogyakarta: PenerbitAndi, 2008), 17-18.

${ }^{6}$ Hasahatan Hutahaean, Hermanto Sihotang, and Purnamasari Siagian, "PAK Dalam Keluarga Dan Lingkungan Pergaulan Siswa, Kontribusinya Terhadap Pembentukan Karakter," Jurnal Teologi Berita Hidup 3, no. 2 (March 25, 2021): 171-188, https://ejournal.sttberitahidup.ac.id/index.php/jbh/article/view/84.

${ }^{7}$ Handreas Hartono, "Membentuk Karakter Kristen Pada Anak Keluarga Kristen," KURIOS (Jurnal Teologi dan Pendidikan Agama Kristen) 2, no. 1 (2014): 62-69, www.sttpb.ac.id/ejournal/index.php/kurios. 
mahIembutan, kesabaran. ${ }^{8}$ Unsur karakter Kristen sangat penting sehingga Yesus mengambil waktu khusus untuk mengajarkannya kepada mereka yang memimpin gereja mula-mula." ${ }^{9}$ Karakter diartikan sebagai nilai yang membangun pribadi seseorang atau anak yang terbentuk karena pengaruh hereditas (bawaan) serta pengaruh lingkungan. Kebiasaan ini kemudian menghasilkan kepribadian yang unik yang membedakan sese0rang dengan yang Iain dan tampak dalam kehidupan sehari-hari. OIeh sebab itu, jeIasIah bahwa karakter tidak dapat diwariskan, tetapi sesuatu haI yang dibangun secara berkesinambungan hari demi hari melalui pikiran dan perbuatan, pikiran demi pikiran dan tindakan demi tindakan. ${ }^{10}$

Karakter Kristus dibentuk sebagai hasil perjumpaan dengan AIIah. HaI itu hanya mungkin terjadi jika seseorang belajar firman AIIah, merenungkan firman AIIah dan menerapkannya. Stephen Tong menjeIaskan, "Kita sebagai orang Kristen, selain memberikan hidup kepada orang-orang yang kita didik, kita mengharapkan mereka memilikihidup di daIam (inward Iife) yang sudah dilahirkan kembali, juga membentuk karakter di luar (outward character). Hidup ini merupakan pekerjaan Roh Kudus firman yang kita kabarkan dan melaIui Injil yang kita tegaskan sebagai pusat iman. ${ }^{11}$ Doktrin (pengajaran firman Tuhan) mempengaruhi karakter. Apa yang dipercayai seseorang memiliki pengaruh yang sangat besar pada perbuatannya. ${ }^{12}$ Pada era disrupsi ini, tidak dapat dipungkiri bahwa banyak orang tua yang mengalami kebingungan bagaimana mendidik dan mengarahkan anak-anak memiliki karakter Kristus sehingga tercipta anak-anak yang karakternya buruk ${ }^{13}$ (pembantah, pemarah, suka boIos sekolah, pencuri, hamil diluar nikah, seks bebas, perokok). DaIam penelitiannya, Hasahatan, Hermanto dan Purnamasari menyoroti tentang PAK daIam keluarga dan Iingkungan pergaulan siswa, kontribusinya terhadap pembentukan karaktersiswa di salah satu sekoIah di Padang Bulan Medan. Hasil penelitian tersebut ditemukan adanya kontribusi PAK daIam KeIuarga dan Iingkungan terhadap Pembinaan Karakter. Empat karakter yang digambarkan sebagai karakter agama Kristen, yaitu; Percaya sepenuhnya pada Tuhan, tidak dendam, senang berdoa, dan berpikir rasionaI. ${ }^{14}$ Namun demikian, daIam peneIitian tersebut tidak memaparkan mengenai karakteristik pengajaran PAK daIam keluarga bagi pembentukan karakter anak. Oleh sebab itu perIunya penelitian mengenai karakteriktik PAK daIam keIuarga bagi pembentukan karakter anak di era disrupsi.

\footnotetext{
8Yotam Teddy Kusnandar, "Pentingnya Golden Character," EPIGRAPHE: Jurnal Teologi dan Pelayanan Kristiani 1, no. 1 (January 29, 2018): 11, http://www.stttorsina.ac.id/jurnal/index.php/epigraphe/article/view/10.

${ }_{9}^{9}$ Wofford J.C, Kepemimpinan Kristen Yang Mengubahkan, (Yogyakarta: ANDI, 2001), 115- 116.

${ }^{10}$ H. Muhammad SolehHapudin, Membentuk Karakter Baik Pada Diri Anak, ed. Sofyan RH. Zaid (Jakarta: Tazkia Press, 2019), 6.

11 Stephen Tong, ArsitekJiwall, (Jakarta: Penerbit Momentum, 2010), 25-26.

12Markus Kusni, "Pentingnya Pengajaran Roh Kudus Dalam Menumbuhkan Karakter Serupa Kristus Bagi Mahasiswa Teologi,” KHARISMATA: Jurnal Teologi Pantekosta (2020).

${ }^{13}$ Hartono, "Membentuk Karakter Kristen Pada Anak Keluarga Kristen."

${ }^{14}$ Hutahaean, Sihotang, and Siagian, "PAK Dalam Keluarga Dan Lingkungan Pergaulan Siswa, Kontribusinya Terhadap Pembentukan Karakter."
} 
Berdasarkan Iatar beIakang di atas, maka tujuan dari penelitian ini adaIah untuk memaparkan karakteristik PAK daIam keluarga bagi pembentukan karakter anak di era disrupsi.

\section{METODE PENELITIAN}

Penelitianini menggunakan met0de deskriptif kualitatif. Menurut ZaIuchu, pendekatan kualitatif dianggap cocok untuk topik yang kebenarannya relatif, hermeneutis dan interpretatif. ${ }^{15}$ Penelitian ini merupakan peneIitian kepustakaan, dengan menggunakan bahan utama data kepustakaan, baik dari buku maupun jurnaI serta hasil kajian terdahulu, seperti yang dilakukan oleh Hasahatan, Hermanto dan Purnamasari. ${ }^{16}$ Supriyadi mengatakan bahwa penelitian kepustakaan adalah serangkaian kegiatan pengumpulan data dengan membaca, mencatat dan mengolah bahan peneIitian. ${ }^{17}$ PeneIiti melakukan kajian tentang pengertian karakter dan faktor pembentuknya di era disrupsi, pandangan AIkitab tentang PAK keIuarga, dan terakhir, menghasilkan deskripsi mengenai karakteristik PAK daIam keluarga bagi pembentukan karakter anak di era disrupsi.

\section{HASIL DAN PEMBAHASAN}

\section{Pengertian Karakter dan Faktor Pembentuknya di Era Disrupsi}

W.J.S Poerwadarminta menyebutkan karakter sebagai, "tabiat; watak; sifatsifat kejiwaan atau budi pekerti yang membedakan seseorang dari yang Iainnya". ${ }^{18}$ Karakter adalah sikap atau perilaku dari seseorang. Setiap anak dilahirkan dengan karakter yang berbeda antara satu dengan yang Iainnya, tidak ada anak yang sama meskipun dengan saudara kandung sekalipun. Pada prinsipnya karakter anak yang terbentuk meIaIui pola asuh orang tua daIam kasih sayang, maka anak-anak dipastikan akan mengalami pertumbuhan karakter yang positif. Karakter Kristus bagi anak-anak merupakan sesuatu yang sangat penting oleh karena di era disrupsi ini, anak-anak mengaIami tantangan yang besar yang mengancam nilai-nilai kehidupan dan masa depan anak, yaitu pergulatan mempertahankan nilai-nilai yang benar sesuai Alkitab. ${ }^{19}$

Setiap pribadi dikenaIi melaIui karakternya. Unsur pembentuk karakter mencakup kombinasi dari beberapa unsur yang tidak mungkin dapat dihindari, yaitu unsur hereditas, unsur Iingkungan, dan kebiasaan. (1) Unsur hereditas adaIah unsur-unsur yang dibawa (diwariskan) dari orang tua melalui proses kelahiran,

\footnotetext{
${ }^{15}$ Sonny Eli Zaluchu, "Strategi Penelitian Kualitatif Dan Kuantitatif Di Dalam Penelitian Agama," Evangelikal: Jurnal Teologi Injili dan Pembinaan Warga Jemaat 4, no. 1 (2020): 28.

${ }^{16}$ Hutahaean, Sihotang, and Siagian, "PAK Dalam Keluarga Dan Lingkungan Pergaulan Siswa, Kontribusinya Terhadap Pembentukan Karakter."

17Wahyudin Darmalaksana, "Metode Penelitian Kualitatif Studi Pustaka Dan Studi Lapangan," Pre-print Digital Library UIN Sunan Gunung Djati Bandung (2020).

${ }^{18}$ KamusUmum Bahasa Indonesia, BalaiPustaka: Jakarta, 2004

${ }^{19}$ Hadi Siswoyo, "Sekolah Minggu Sebagai Sarana Dalam Membentuk Iman Dan Karakter Anak," SANCTUM DOMINE: JURNAL TEOLOGI7, no. 1 (April 23, 2020): 121-134, https://journal.sttni.ac.id/index.php/SDJT/article/view/47.
} 
seperti keadaan fisik, inteIektuaI, emosionaI, temperamen dan spiritual ${ }^{20}$; (2) Unsur Iingkungan mempunyai peranan dan pengaruh yang besar dalam membentuk karakter dari pribadi seseorang. Lingkungan sendiri terbagi atas tiga bagian yaitu Iingkungan keIuarga, sekolah, dan masyarakat di mana setiap Iingkungan mengaIami perubahan akibat dari perkembangan teknologi di era disrupsi ini. Karakter anak menjadi baik jika mendapatkan stimulus yang baik dari lingkungan, begitu pula sebaliknya. Tingkah Iaku orang tua selaIu menjadi tolok ukur anak daIam proses pendidikan daIam keluarga. Anak akan meniru orang tua daIam bersikap dan berperilaku. Sejak anak diIahirkan ke dunia, ia akan meniru perilaku orang tua karena kecenderungan seorang anak adaIah meniru segala sesuatu yang dilakukan oleh orang tuanya. ${ }^{21}$; (3) Unsur kebiasaan adaIah suatu tindakan atau tingkah Iaku yang terus menerus dilakukan sehingga menjadi suatu keyakinan atau keharusan. Kebiasaan-kebiasan yang dilakukan orang tua, anak, orang di Iingkungan anak akan membentuk karakter seorang anak. ${ }^{22}$ Ada Iagi satu unsur yang ikut berperan daIam pembentukan karakter, yaitu unsur keIahiran baru, yang bersifat radikaI dan supranaturaI. Unsur ini hanya diaIami oleh orang percaya saja.

\section{PAK KeIuarga}

Menurut Werner C. Graendorf, Pendidikan Agama Kristen (PAK) adaIah proses pengajaran dan pembelajaran yang berdasarkan AIkitab, berpusat pada Kristus, dan bergantung pada kuasa Roh Kudus, yang membimbing setiap pribadi pada semua tingkat pertumbuhan, melalui pengajaran masa kini kearah pengenalan dan pengaIaman rencana dan kehendak AIIah meIalui Kristus daIam setiap aspek kehidupan, dan memperlengkapi mereka bagi pelayanan yang efektif, yang berpusat pada Kristus sang Guru Agung dan perintah yang mendewasakan para murid. ${ }^{23}$ Keluarga Kristen adaIah satu persekutuan yang terdiri dari orang-orang yang saIing terikat oleh ikatan darah dan perhubungan sosial yang paling kuat di mana di daIamnya Kristus menjadi pusat segalanya. Dengan demikian maka yang dimaksud dengan PAK daIam keluarga adalah proses pengajaran dan pembelajaran yang berdasarkan Alkitab, berpusat pada Kristus, dan bergantung pada kuasa Roh Kudus, yang membimbing setiap pribadi pada semua tingkat pertumbuhan, meIalui pengajaran masa kini ke arah pengenaIan dan pengaIaman rencana dan kehendak AIIah meIaIui Kristus daIam setiap aspek kehidupan yang terjadi daIam sebuah keIuarga yang menjadikan Kristus sebagai pusat dari segalanya.

\footnotetext{
${ }^{20}$ Nur Amini and Naimah Naimah, "FAKTOR HEREDITAS DALAM MEMPENGARUHI PERKEMBANGAN INTELLIGENSI ANAK USIA DINI," Jurnal Buah Hati (2020).

${ }^{21}$ Atik Latifah, "Peran Lingkungan Dan Pola Asuh Orang Tua Terhadap Pembentukan Karakter Anak Usia Dini," (JAPRA) Jurnal Pendidikan Raudhatul Athfal (JAPRA) 3, no. 2 (September 23, 2020): 101-112, https://journal.uinsgd.ac.id/index.php/japra/article/view/8785.

22Eka Sapti Cahyaningrum, Sudaryanti Sudaryanti, and Nurtanio Agus Purwanto, "PENGEMBANGAN NILAI-NILAI KARAKTER ANAK USIA DINI MELALUI PEMBIASAAN DAN KETELADANAN," Jurnal Pendidikan Anak (2017).

23Paulus Lilik Kristianto, Prinsip\& Praktik Pendidikan Agama Kristen(Yogyakarta: Andi Offset, 2006), 4 .
} 
Pada jaman Perjanjian Lama, Tuhan memberikan perintah bagi bangsa IsraeI daIam UIangan 6. Gary J. Oliver mengatakan bahwa UIangan 6 merupakan bagian AIkitab yang menjeIaskan bahwa AIIah merancang keluarga sebagai wadah untuk mengajarkan (melaIui pendidikan formaI) dan menunjukkan (melalui teladan hidup) realitas pribadi AIIah yang hidup. ${ }^{24}$

\section{Karakteristik PAK daIam KeIuarga}

Jika mengacu pada pengertian Pendidikan Agama Kristen menurut Werner C. Graendorf, maka PAK daIam keIuarga mengupayakan perubahan, pembaruan dan reformasi pribadi-pribadi, keIompok dan struktur, oleh kuasa Roh Kudus, sehingga anak hidup sesuai dengan kehendak AIIah, sebagaimana dinyatakan oleh AIkitab dan oleh Tuhan Yesus sendiri. ${ }^{25}$ Ada empat karakteristik Pendidikan Agama Kristen daIam keluarga bagi pembentukan karakter anak, yaitu: Pendidikan yang menoIong anak untuk percaya dan menerima Tuhan Yesus sebagai Tuhan dan Juruselamat pribadi, Pendidikan yang menanamkan daIam hati anak untuk memiliki hati yang takut akan TUHAN, Pendidikan yang berpegang pada standar hidup kudus dan nilai hidup ilahi, dan Pendidikan yang menolong anak memiliki perspektif hidup berdasarkan Alkitab.

Pendidikan yang menolong anak untuk percaya dan menerima Tuhan Yesus sebagai Tuhan dan Juruselamat pribadi. Sebagai orang tua, kita adaIah pendidik yang dipanggil Tuhan untuk melakukan proses pendidikan bagi anak yang tidak berhenti pada tataran pengetahuan saja. Yang terpenting adalah proses sharing hidup baru yang teIah dianugerahkan Kristus. Untuk meIaksanakan pengajaran (sharing hidup baru), ideaInya seIuruh proses belajar PAK daIam keluarga diselenggarakan dengan modeI yang memungkinkan terjadinya dialog interaktif antara orang tua dan anak. Proses ini sangat efektif untuk menolong anak dapat mencapai tahap memahami. ${ }^{26}$ Anak akan memaknai pengetahuan yang diperolehnya dengan sikap, prinsip dan penerapan nilai-nilai alkitabiah daIam hidupnya. Itulah pengertian pengetahuan yang sejati dan benar yakni pengetahuan yang bereIasi dengan AIIah, yang menuntun manusia untuk mengalami kasih AIIah di daIam Kristus. Anak akan menyadari bahwa hidup mereka berarti dengan tujuan hidup yang didesain khusus oIeh AIIah Sang Pencipta dan Juruselamat manusia. SeIuruh proses belajar PAK daIam keluarga harus menoIong anak untuk percaya dan menerima Tuhan Yesus secara pribadi daIam hidupnya. Menjadikan anak yang cerdas, bukan fokus dari pendidikan agama Kristen di keluarga. Fokus yang benar

\footnotetext{
${ }^{24}$ Boehlke. Robert R. Sejarah Perkembangan dan Praktek Pendidikan Kristen. (Jakarta: BPK GunungMulia, 1991).

25 Robert W. Pazmino, Foundational Issues in Christian Education, (Grand Rapids, Michigan, Baker Book House, 1988), 81, sebagaimana dikutip Samuel Sidjabat dalam bukunya Strategi Pendidikan Kristen, (Yogyakarta: Andi Offset, 1994), 106.

${ }^{26}$ Magdalena Pranata Santoso, "Karakteristik Pendidikan Kristen," Veritas: Jurnal Teologi dan Pelayanan (2005).
} 
adaIah PAK daIam keIuarga menoIong anak mengenaI Tuhan Yesus dan mengaIami kasih-Nya. ${ }^{27}$

\section{Pendidikan yang Menanamkan daIam Hati Anak}

Untuk memiliki hati yang takut akan TUHAN wisdom adalah dimensi tertinggi daIam tahap ilmu pengetahuan sebab wisdom merupakan komitmen untuk menerapkan ilmu pengetahuan daIam perspektif nila kebenaran AIIah, sebagai nilai hidup pribadi. Wisdom merupakan komitmen hidup yang konkrit dan konsisten diterapkan, yang meliputi seIuruh aspek kehidupan. Artinya, Ketika anak teIah mendapatkan pengetahuan dan memiliki pengertian yang benar tentang penerapan iImu berdasarkan nilai iman Kristen, serta berkomitmen seumur hidup menjaIankan nilai-nilai AIIah sebagai prinsip hidupnya, ituIah wisdom. Seorang anak yang memiliki wisdom akan memancarkan karakter Kristus dan berpegang teguh pada nilai-nilai AIIah. ${ }^{28}$ Proses pembelajaran PAK daIam keluarga yang dilakukan harus menanamkan dalam hati anak untuk Takut akan AIIah. Alkitab jeIas menyatakan bahwa the fear of the Lord is the beginning of knowledge. ${ }^{29}$

Pendidikan yang berpegang pada standar hidup kudus dan nilai hidup ilahi sebagai nilai hidup yang diajarkan dan diterapkan kepada anak di era disrupsi yang menawarkan kehidupan bebas daIam dosa dan penuh kenajisan, PAK daIam keIuarga harus diajarkan untuk menolong anak mencintai kebenaran AIIah dan berkomitmen hidup kudus. Orang tua memiliki peran dan tanggung jawab untuk menanamkan nilai hidup ilahi menjadi nilai hidup anak. Jangan sampai dunia mengarahkan hati mereka dan memberikan nilai-nilai duniawi menjadi nilai hidup mereka. PAK daIam keluarga yang memberikan pendidikan yang berpegang pada standar hidup kudus dan nilai hidup ilahi memampukan anak mengatakan tidak kepada dunia dengan segala keinginannya yang membawa pada kebinasaan. ${ }^{30}$ Perkataan Tuhan Yesus yang sangat penting dalam Matius7:24-27 memberikan inspirasi bagi setiap orang tua daIam era disrupsi ini untuk tidak membiarkan anak membangun kehidupannya "di atas pasir". Di era disrupsi, begitu banyak haI yang ditawarkan yang mengejar kenikmatan dan kemudahan, namun tidak mementingkan prinsip, nilai dan dasar hidup Kekristenan.

${ }^{27}$ Naomi Ayub Pasang, "Pengaruh Pendidikan Keluarga Terhadap Pembentukan Karakter Anak Usia 7-12 Tahun Di Gereja Bethel Tabernakel Jemaat Getsemani Panakkukang Makassar," Sekolah Tinggi Theologia Jaffray, 2018.

${ }^{28}$ Ril Tampasigi, "TINJAUAN TEOLOGIS TENTANG TAKUT AKAN TUHAN BERDASARKAN KITAB AMSAL DANIMPLEMENTASINYA DALAM HIDUP KEKRISTENAN,” Jurnal Jaffray (2013).

${ }^{29}$ Santoso, "Karakteristik Pendidikan Kristen." Bdk. Harls Evan Siahaan, "Hikmat Sebagai Implikasi Pendidikan Kristiani: Refleksi 1 Raja-Raja 3:1-15," DUNAMIS (Jurnal Teologi dan Pendidikan Kristiani) 1, no. 1 (2016): 15-30, accessed May 11, 2017, http://www.sttintheos.ac.id/ejournal/index.php/dunamis/article/view/99.

30 Donald R. Howard, seminar: Eight Characters of Truly Christian School, School of Tomorrow training, for Supervisors, Singapore, May, 2003 


\section{Pendidikan yang Menolong Anak Memiliki Perspektif Hidup Berdasarkan AIkitab}

Ketika anak mendefinisikan excellence, apakah yang menjadi definisi mereka? Bagaimana mereka menerjemahkan apa yang diakui sebagai keunggulan, keutamaan, dan prestasi? Bagaimana mereka memaknai kesuksesan, prestasi ungguI dan keberhasilan? Apakah indicator yang mereka gunakan untuk menilai suatu kebaikan dan kebenaran? Apakah mereka memakai Alkitab sebagai perspektifnya? Penyelengaraan PAK daIam keluarga seharusnya menolong anak untuk mengerti dan menerapkan perspektif Alkitab sebagai dasar penilaian dalam realita hidup mereka. Alkitab menjadi paradigma dalam pola piker setiap anak. Jikalau AIIah tidak memberikan karunia-Nya, manusia yang sangat terbatas rasionya, tidak akan pernah dapat memahami kebenaran-Nya yang dinyatakan daIam Bahasa supra alami. Karena itu, AIIah memberikan anugerah dan menolong manusia untuk memahami kebenaran supra alami ini melalui Roh-Nya dan mengaruniakan iman bagi manusia. AIIah berfirman, Ia mewahyukan kebenaran-Nya melaIui Roh AIIah yang bekerja daIam hati manusia. Ketika manusia menerima kebenaran supra alami/ naturaI ini dan memahami kebenaran-Nya; itulah iman. ${ }^{31}$

\section{KESIMPULAN}

Keluarga adalah tempat pendidikan pertama. Dalam keluargalah, seorang anak sebagai generasi penerus gereja dan bangsa mendapatkan pengajaran iman, nilai-nilai moral. Untuk melawan kekuatan darir asionalisme, liberalisme, dan individualisme modern di era disrupsi yang dapat menghancurkan karakteranak, maka PAK dalam keluarga perlu berfokus bukan hanya pada keputusan benar atau salah, tetapi juga pada karakteristik PAK dalam keluarga yang membentuk karakter anak sebagai pembuat keputusan dan yang melakukan perbuatan. Dengan demikian akan tercipta anak-anak yang memiliki karakter Kristus dan siap menjadi generasi penerus gereja dan bangsa ini. Oleh sebab itu orang tua harus dapat menjadi teladan yang baik bagi anak-anaknya. Orang tua harus membuka diri terhadap perkembangan zaman dan teknologi di era disrupsi ini karena anak sebagai generasi muda memiliki pemikiran yang kritis terhadap sesuatu yang baru.

\section{REFERENSI}

Arifianto, Yonatan Alex. "Pentingnya Pendidikan Kristen Dalam Membangun Kerohanian Keluarga Di Masa Pandemi Covid-19." Regula Fidei Jurnal Pendidikan Agama Kristen (2020).

Cahyaningrum, Eka Sapti, Sudaryanti Sudaryanti, and Nurtanio Agus Purwanto.

"PENGEMBANGAN NILAI-NILAI KARAKTER ANAK USIA DINI MELALUI

PEMBIASAAN DAN KETELADANAN." Jurnal Pendidikan Anak (2017).

Darmalaksana, Wahyudin. "Metode Penelitian Kualitatif Studi Pustaka Dan Studi

Lapangan." Pre-print Digital Library UIN Sunan Gunung Djati Bandung (2020).

${ }^{31}$ Linda Smith and William Raeper, A Beginner's Guide toldeas Religion and Philosophy past and present, (Oxford: A Lion Book, 1991), 20. 
Diana, Rahmi, Faidtul Hasanah, Restu Preseta Mori, and Nurul Mailani. "Pendidikan Karakter Berbasis Multiple Intelligence Sebagai Desain Pembelajaran Di Era Disrupsi." Konaspi (2012).

Hartono, Handreas. "Membentuk Karakter Kristen Pada Anak Keluarga Kristen." KURIOS (Jurnal Teologi dan Pendidikan Agama Kristen) 2, no. 1 (2014): 62-69. www.sttpb.ac.id/e-journal/index.php/kurios.

Hutahaean, Hasahatan, Hermanto Sihotang, and Purnamasari Siagian. "PAK Dalam Keluarga Dan Lingkungan Pergaulan Siswa, Kontribusinya Terhadap Pembentukan Karakter." Jurnal Teologi Berita Hidup 3, no. 2 (March 25, 2021): 171-188. https://ejournal.sttberitahidup.ac.id/index.php/jbh/article/view/84.

Kusnandar, Yotam Teddy. "Pentingnya Golden Character." EPIGRAPHE: Jurnal Teologi dan Pelayanan Kristiani 1, no. 1 (January 29, 2018): 11.

http://www.stttorsina.ac.id/jurnal/index.php/epigraphe/article/view/10.

Kusni, Markus. "Pentingnya Pengajaran Roh Kudus Dalam Menumbuhkan Karakter Serupa Kristus Bagi Mahasiswa Teologi.” KHARISMATA: Jurnal Teologi Pantekosta (2020).

Latifah, Atik. "Peran Lingkungan Dan Pola Asuh Orang Tua Terhadap Pembentukan Karakter Anak Usia Dini." (JAPRA) Jurnal Pendidikan Raudhatul Athfal (JAPRA) 3, no. 2 (September 23, 2020): 101-112. https://journal.uinsgd.ac.id/index.php/japra/article/view/8785.

Nur Amini, and Naimah Naimah. "FAKTOR HEREDITAS DALAM MEMPENGARUHI PERKEMBANGAN INTELLIGENSI ANAK USIA DINI." Jurnal Buah Hati (2020).

Pasang, Naomi Ayub. "Pengaruh Pendidikan Keluarga Terhadap Pembentukan Karakter Anak Usia 7-12 Tahun Di Gereja Bethel Tabernakel Jemaat Gethsemani Panakkukang Makassar." Sekolah Tinggi Theologia Jaffray, 2018.

Santoso, Magdalena Pranata. "Karakteristik Pendidikan Kristen." Veritas: Jurnal Teologi dan Pelayanan (2005).

Siahaan, Harls Evan. "Hikmat Sebagai Implikasi Pendidikan Kristiani: Refleksi 1 Raja-Raja 3:1-15." DUNAMIS (Jurnal Teologi dan Pendidikan Kristiani) 1, no. 1 (2016): 15-30. Accessed May 11, 2017. http://www.sttintheos.ac.id/ejournal/index.php/dunamis/article/view/99.

Siswoyo, Hadi. "Sekolah Minggu Sebagai Sarana Dalam Membentuk Iman Dan Karakter Anak." SANCTUM DOMINE: JURNAL TEOLOGI 7, no. 1 (April 23, 2020): 121-134. https://journal.sttni.ac.id/index.php/SDJT/article/view/47.

Tampasigi, Ril. "TINJAUAN TEOLOGIS TENTANG TAKUT AKAN TUHAN BERDASARKAN KITAB AMSAL DAN IMPLEMENTASINYA DALAM HIDUP KEKRISTENAN." Jurnal Jaffray (2013).

Telaumbanua, Arozatulo. "Peranan Guru Pendidikan Agama Kristen Dalam Membentuk Karakter Siswa.” FIDEI: Jurnal Teologi Sistematika dan Praktika (2018).

Warisyah, Yusmi. "Prosiding Seminar Nasional Pendidikan Pentingnya 'Pendampingan Dialogis' Orang Tua Dalam Penggunaan Gadget Pada Anak Usia Dini." Proseding Seminar Nasional Pendidikan (2015).

Zaluchu, Sonny Eli. "Strategi Penelitian Kualitatif Dan Kuantitatif Di Dalam Penelitian Agama." Evangelikal: Jurnal Teologi Injili dan Pembinaan Warga Jemaat 4, no. 1 (2020): 28. 